\title{
PRESENT-DAY GLACIERS IN THE U.S.S.R. AND SOME DATA ON THEIR MASS BALANGE*
}

\author{
By M. G. Grosval'd and V. M. Kotlyakov \\ (Institut Geografii Akademii Nauk SSSR, Moscow, U.S.S.R.)
}

\begin{abstract}
There are four major glacier regions in the U.S.S.R.: the Atlantic-Arctic, Atlantic-Eurasian, East Siberian and Pacific-Asian, which can be divided into 19 separate glacier areas. The total area of the glaciers in the country amounts to $81900 \mathrm{~km}^{2}$, and the volume of water stored in them to $13750 \mathrm{~km}^{3}$.

The main characteristic features of glacier regime, such as the elevation of the equilibrium line, the value of the total accumulation at the equilibrium line, the vertical gradients of net balance, the "glacier ratios", etc., are estimated for the majority of the glacier areas. The data on mass balance of the glaciers in the Polar Urals and Tien Shan which were obtained by direct measurement during the last decade are tabulated and compared. It has been found that the glacier balance changes in the two areas are nonsynchronous.

A comparison of the variations in mass balance of the Lednik IGAN in the Polar Urals, and the Grosser Aletschgletscher in the Swiss Alps, over a period of several decades suggests a cyclic trend of the variations in both regions (with a wave-length of about 22 years), and the direct opposition in their phase. The analogy of 22-year cycles of the balance variations with the cyclic fluctuations of the same wave-length in solar activity seems to be quite evident, whereas the atmospheric circulation appears to be one of the main intermediate variables in the chain sun-glaciers responsible for the out-of-phase relationship in glacier variations of certain areas.

In conclusion, some data on the present changes in glacier regime are given, as well as general information on glaciological studies carried on in the U.S.S.R. within the framework of the I.H.D. programmes. The latter include the compilation of the Soviet Union inventory of perennial snow and ice masses, the continuous measurement of glacier variations, and the research on combined heat, mass and water balances at selected
\end{abstract} mountain glacier basins.

RÉsumé. Glaciers actuels en U.R.S.S. et quelques données sur leur bilan de masse. En U.R.S.S., il existe quatre régions principales englacées: Atlantique-Arctique, Atlantique-Eurasienne, Est-Sibérienne et PacifiqueAsiatique, qui peuvent être divisées en 19 régions distinctes avec des glaciers. La surface totale couverte par des glaciers est de $81900 \mathrm{~km}^{2}$, et le volume de l'eau stockée est de $13750 \mathrm{~km}^{3}$.

Les caractéristiques principales du régime des glaciers, commel'altitude de la ligned'équilibre, les gradients verticaux du bilan spécifique, l'énergie des glaciers, etc., sont estimées pour la majorité des surfaces englacées. Les données du bilan de masse des glaciers de l'Oural arctique et du Tien Shan sont présentées sous forme de tableaux comparatifs, données obtenues par mesure directe durant la dernière décennie. Il a été trouvé que le bilan des glaciers dans ces deux zones n'est pas synchrone.

Une comparaison des variations des bilans de masse du Lednik IGAN dans l'Oural arctique et du Grand Glacier d'Aletsch dans les Alpes Suisses pendant une période de plusieurs décades suggère une tendance cyclique des variations dans ces deux zones (avec une longueur d'onde de 22 ans) en directe opposition de phase. L'analogie des cycles de 22 ans des variations du bilan avec les fluctuations cycliques de la même longueur d'onde de l'activité solaire semble presqu'évidente, et ainsi la circulation atmosphérique apparaît comme l'une des principales variables intermédiaires dans la chaine soleil-glaciers responsable de la relation en opposition de phase des variations des glaciers dans certaines zones.

En conclusion, quelques données sur les changements actuels du régime des glaciers sont présentées, comme information générale des études glaciologiques effectuées en U.R.S.S. dans le cadre des programmes de la Décennie Hydrologique Internationale. Ceux-ci couvrent en particulier la compilation de l'inventaire en Union Soviétique des masses de neige et de glace pérénnielles, la mesure continue des variations des glaciers, et l'étude des bilans combinés de chaleur, de masse et d'eau pour des bassins versants sélectionnés de glaciers.

Zusammenfassung. Die gegenwärtigen Gletscher in der UdSSR und einige Daten über ihren Massenhaushalt. In der UdSSR gibt es vier grössere Gletscherregionen: die Atlantisch-Arktische, die Atlantisch-Eurasische, die Ostsibirische und die Pazifisch-Asiatische: sie können in 19 einzelne Gletschergebiete aufgeteilt werden. Die Gesamtfläche der Gletscher im Land beträgt $81900 \mathrm{~km}^{2}$, das in den Gletscher gespeicherte Wasservolumen $13750 \mathrm{~km}^{3}$.

Die Hauptmerkmale des Gletscherverhaltens wie etwa die Höhe der Gleichgewichtslinie, der Wert der Gesamtakkumulation an der Gleichgewichtslinie, die Vertikalgradienten der Nettobilanz, die "Glacier Ratios" etc. werden für die meisten Gletschergebiete abgeschätzt. Die aus direkten Messungen während der letzten Dekade gewonnenen Werte für den Massenhaushalt der Gletscher im polaren Ural und im Tien Shan sind tabelliert und werden miteinander verglichen. Es wurde festgestellt, dass die Bilanzschwankungen der Gletscher in den beiden Gebieten nicht synchron verlaufen.

* The text of a paper read at the Glaciological Training Course in Kebnekaise, Swedish Lapland, August 1967. 
Ein Vergleich der Veränderungen der Haushalte des IGAN-Gletschers im polaren Ural und des Grossen Aletschgletschers in den Schweizer Alpen über einige Dekaden lässt einen zyklischen Ablauf der Schwankungen in beiden Gebieten mit einer Periode von $c a .22$ Jahren annehmen, jedoch unter genau entgegengesetzten Phasen. Die Analogie zwischen den 22-Jahre-Zyklen der Bilanzschwankungen und der zyklischen Fluktuation der Sonnenaktivität mit derselben Periode tritt deutlich zutage, während die atmosphärische Zirkulation eines der wesentlichen Zwischenglieder in der Kette Sonne-Gletscher zu sein scheint, das für die Gegenläufigkeit der Gletscherschwankungen in bestimmten Gebieten verantwortlich ist.

Abschliessend werden einige Daten über die gegenwärtigen Veränderungen im Gletscherverhalten sowie allgemeine Angaben über die im Rahmen des IHD-Programms in der UdSSR durchgeführten glaziologischen Studien mitgeteilt. Diese umfassen die Aufstellung des Inventars ständiger Schnee- und Eismassen in der Sowjet-Union, die fortlaufende Messung von Gletscherschwankungen und Untersuchungen über den kombinierten Wärme-, Massen- und Wasserhaushalt in ausgewählten Gebirgsgletscherbecken.

\section{Glacier Regions and Glacier Areas}

The U.S.S.R. has a very extensive territory, and there is considerable variation in climate and topography within the country. The combinations of these environmental features which are favourable for the existence of glaciers occur in a number of areas. These areas of glacierization are shown in Figure $\mathrm{I}$.

The glacier areas can be grouped into several regions, distinguished by both their geographical position and the origin of the moisture-bearing air masses responsible for the nourishment of the glaciers.

The first glacier region is situated in the Arctic and lies within the zone of cyclones coming from the North Atlantic. Therefore this region can be called the Atlantic-Arctic. Apparently, it is part of a larger region which in addition includes the glacier areas of Iceland, Scandinavia, Svalbard and, perhaps, the north-eastern part of Greenland. Within this region in the Soviet Union lie Zemlya Frantsa-Iosifa, Novaya Zemlya, Severnaya Zemlya, the sub-polar and Polar Urals, the Byrranga mountains (Taymyr peninsula), and the small islands of Viktoriya, Ushakova and De Longa.

The second region includes the mountain glacier areas extending along the southern borders of the country. They are also under the influence of the Atlantic air masses which is spread over a considerable part of Eurasia. Hence it can be called the Atlantic-Eurasian region. It embraces the glacier areas of the Caucasus, the Alay and Pamir mountains, Tien Shan, Dzhungar Alatau, the Altay and East Sayan mountains. Some of these, in particular, the Pamir, Tien Shan and the Altay glacier areas are crossed by the frontier and only their northern parts lie within the U.S.S.R.

The third region includes the outlying ranges of the East Siberian Highlands; the Kodar, Suntar Khayata, Verkhoyansk and Chertskiy mountains belonging to it. They are also under the influence of the Atlantic Ocean, but in some seasons of the year they are influenced by the Pacific Ocean as well. The influence of the latter is particularly marked in the Suntar Khayata area. Almost the whole of this glacier region was discovered only comparatively recently, in the I940's and I950's, and quite unexpectedly, since, according to previous ideas glaciers could not have formed in such a markedly continental climate as characterizes East Siberia. This region may be called the East Siberian.

Finally, the fourth region is comprised of the mountain chains along the Pacific coasts and includes the two glacier areas of Kamchatka and Koryak mountains. The Pacific Ocean is the main source of nourishment of the glaciers there and the region can be called the Pacific-Asian.

We can speak now of 4 large glacier regions in the U.S.S.R. which can be divided into as many as 19 separate glacier areas. Of these, I4 have a mountain type of glacierization, and 5 , belonging to the Arctic Islands, have comparatively small ice caps.

\section{Ice Areas and Ice Volumes}

Thanks to air survey and detailed topographic mapping of the whole of the territory of the U.S.S.R., we now have at our disposal relatively reliable data for the calculation of the areas 


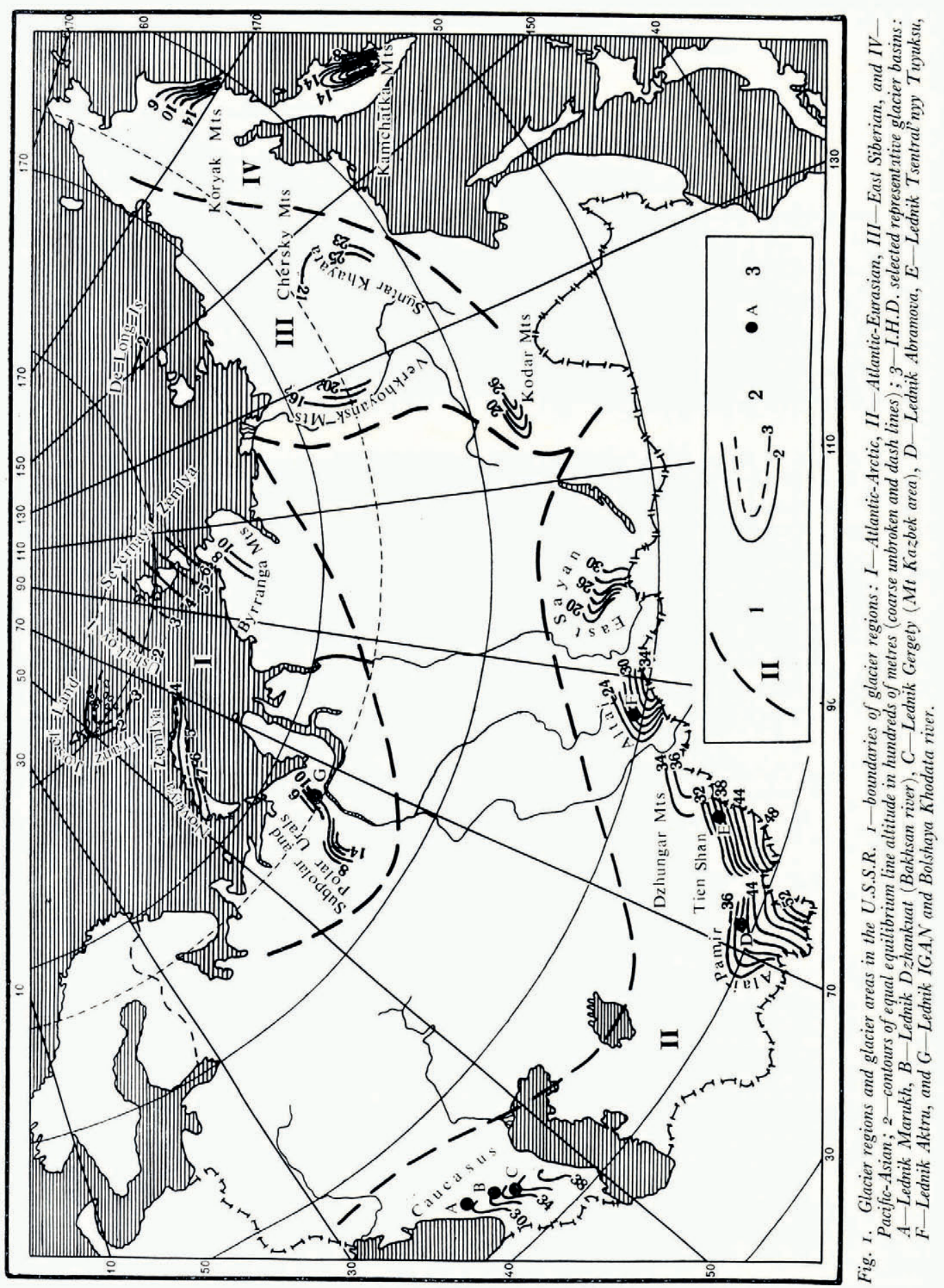


of existing glaciers and the amounts of water stored in them. However, the interpretation of air photographs in terms of the identification of glaciers is as yet far from complete for many of the areas.

Though the figures now available are therefore more or less preliminary they are in the process of being verified for the preparation and compilation of the glacier inventory of the U.S.S.R. In some areas (e.g. Zemlya Frantsa-Iosifa and the Caucasus) the area of glacier ice according to the inventory proves to be smaller than the earlier figures. This is due not so much to the shrinkage of glaciers during the last decades as to the errors in former maps. In some comparatively poorly investigated areas (e.g. in the Pamir and Tien Shan) the area of glaciers tends to become somewhat larger in the latest calculations.

There are very few data on the depth of glacier ice. The first comprehensive measurements of ice thicknesses were made as recently as the International Geophysical Year 1957-59. To estimate the average values of ice thickness over all the glacierized areas one must apply the results of the isolated direct measurements (bore holes, seismic soundings, etc.) to the numerous glaciers which are unmeasured, but similar morphologically to those already measured. Thus we have to resort to generalization and extrapolation, and it is possible therefore to obtain only approximate and somewhat tentative figures.

All the mountain glaciers, in terms of their thickness, may be roughly divided into three groups. The first group, wall-sided and cirque glaciers, predominate in the Urals, the west Caucasus and in some parts of the Altay and East Siberia. The maximum depth of such glaciers may reach 70-90 $\mathrm{m}$ but, as a rule, does not exceed $50-60 \mathrm{~m}$. Cirque-valley and normal valley glaciers form the second group. Their predominant maximum thickness is somewhat over I $00 \mathrm{~m}$. Large valley and dendritic glaciers and also transection glacier systems compose the third group. Within the U.S.S.R. they are met with only in the mountains of central Asia. They are several hundred metres thick and the biggest of them are as thick as 6oo-90o m.

The average depth values of each of the above-mentioned groups are, of course, smaller than these maximum values because of the thinning of the ice at the marginal and terminal parts of the glaciers. Besides, the mean ice depth for certain areas characterized by comparatively intensive glacierization must be somewhat reduced in view of the fact that in each of these areas, together with the large glaciers, many wall-sided and cirque glaciers of inconsiderable thickness occur. Taking this into account, the average depth of $30-50 \mathrm{~m}$ was adopted for the first group, $70-100 \mathrm{~m}$ for the second, and $200-300 \mathrm{~m}$ for the third. More detailed accounts of these computations and their results have been given in papers by Kotlyakov (1966) and Avsyuk and Kotlyakov (1967). The values obtained are given in Table I.

This table suggests that at present $2800 \mathrm{~km}^{3}$ of ice, i.e. $2400 \mathrm{~km}^{3}$ of water are stored in the mountain glaciers on the territory of the U.S.S.R. (the latest figures for these glaciers has been given by Avsyuk and Kotlyakov (1967)). Much more ice exists in the ice caps of the Soviet Arctic, about $12700 \mathrm{~km}^{3}$ of ice (i.e. $10900 \mathrm{~km}^{3}$ of water) are concentrated on just the three groups of islands of Zemlya Frantsa-Iosifa, Novaya Zemlya and Severnaya Zemlya. Altogether, the glacierized areas in the U.S.S.R. cover $81900 \mathrm{~km}^{2}$, and more than $1375^{\circ} \mathrm{km}^{3}$ of water are stored in glaciers there.

\section{Main Characteristic Features of Glacier Regime}

To obtain an idea of the mass balance we can consider such parameters as the elevation of the equilibrium line, the intensity of accumulation and ablation processes (expressed by the value of the total accumulation at the elevation of the equilibrium line, vertical accumulation and ablation gradients and their sum, the vertical net balance gradient. The latter is very close to the "glacierization energy" of Shumskiy and to the "activity index" of Meier and Post (1962). 
Table I. Areas, Thicknesses and Volumes of Glaciers

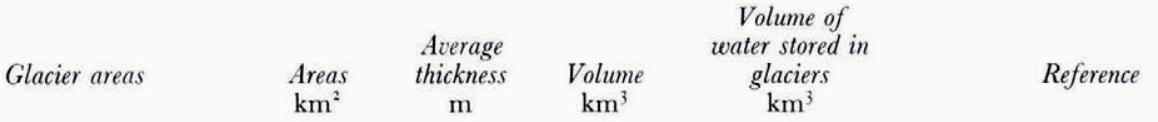

Zemlya Frantsa-Iosifa
Novaya Zemlya
Severnaya Zemlya
Ostrov Ushakova
Ostrova De Longa
Gory Byrranga
Ostrov Viktoriya
Polar \& sub-polar Urals
$\quad$ Total:

Atlantic-Arctic region

\begin{tabular}{|c|c|c|c|c|}
\hline \multirow[b]{2}{*}{ 13735 } & & \multirow[b]{2}{*}{$\begin{array}{l}\text { Grosval'd and others (in } \\
\text { press) }\end{array}$} \\
\hline & I8o & 2500 & $225^{\circ}$ & \\
\hline 24300 & 290 & $705^{\circ}$ & $6 o_{3}$ & Chizhov and others (1968) \\
\hline 17500 & 200 & 3500 & 3010 & Govorukha ( 1965 ) \\
\hline 325 & 200 & 55 & $5^{\circ}$ & Govorukha (I966) \\
\hline 67 & 120 & 8 & 7 & Shumskiy (1949) \\
\hline 50 & 50 & 2.5 & 2.5 & $\begin{array}{l}\text { Miroshnikov (1962), } \\
\text { Govorukha (in press) }\end{array}$ \\
\hline 6 & 80 & 0.5 & 0.5 & $\begin{array}{l}\text { Grosval'd and others (in } \\
\text { press) }\end{array}$ \\
\hline 28 & 40 & I & I & Troitskiy and others (1966) \\
\hline 6 I 000 & & I3 100 & I I $35^{\circ}$ & \\
\hline
\end{tabular}

\section{Caucasus}

Alay \& Pamir

Tien Shan

Dzhungar mountains

Altay

East Sayan

Total:

Kodar mountains

Suntar Khayata

Verkhoyansk mountains

Chertskiy range

Total:

Koryak mountains

Kamchatka mountains

Total:

Total for the territory of the USSR

\section{Atlantic-Eurasian region}

$\begin{array}{rrrr}\text { 1 } 805 & 75 & \text { 1 } 42 & 122 \\ 9375 & \text { 180 } & \text { 1 } 680 & \text { 1 } 445 \\ 6 \text { 190 } & \text { 1 } 15 & 725 & 624 \\ & & & 82 \\ 956 & \text { 100 } & 96 & 60 \\ 646 & \text { 105 } & 69 & \end{array}$

$3^{2}$
19000

$\begin{array}{rr}40 & 1 \\ 2700\end{array}$

East Siberian region

$\begin{array}{rrrr}15 & 80 & 1 & 1 \\ 206 & 100 & 21 & 18 \\ 23 & 50 & 1 & 1 \\ 162 & 85 & 14 & 12 \\ 400 & & 40 & 30\end{array}$

\section{Pacific-Asian region}

\begin{tabular}{|c|c|c|c|c|}
\hline 650 & 50 & $3^{2}$ & 28 & $\begin{array}{l}\text { Malykh (1958), Svatkov } \\
\text { and Tsvetkov (1965) }\end{array}$ \\
\hline 866 & 70 & $6 \mathrm{I}$ & 53 & Ivan'kov (1958) \\
\hline I 500 & & 90 & 80 & \\
\hline
\end{tabular}

$81900 \quad 1595^{\circ} \quad 1375^{\circ}$

$$
\begin{aligned}
& \text { Ivan'kov ( } 1959 \text { [a], [b]) } \\
& \text { Zabirov (1955, 1958) } \\
& \text { Zabirov (1958), Zenkova } \\
& \text { ( } 1960) \\
& \text { Zenkova (1959) } \\
& \text { Tronov ( I } 949 \text { ), Donchenko } \\
& \text { Grosval'd (I965) }
\end{aligned}
$$

$$
\begin{aligned}
& \text { Preobrazhenskiy (196o) } \\
& \text { Koreysha (1963), Grave } \\
& \text { ( } 1967 \text { ) } \\
& \text { Vas'kovskiy (1955), } \\
& \text { Preobrazhenskiy ( } 1963 \text { ) } \\
& \text { Vas'kovskiy (1955), } \\
& \text { Preobrazhenskiy ( } 1963) \text {, } \\
& \text { Grave (1967) }
\end{aligned}
$$

Another important parameter which reflects the glacier mass balance is the "glacier ratio" $(K)$, which, in Soviet terminology, is the ratio of the accumulation area $\left(S_{\mathrm{c}}\right)$ to the ablation area $\left(S_{\mathrm{a}}\right)$. This ratio can be easily converted into Meier's "accumulation area ratio" ( $k$ ) (Meier and Post, I962) which is the ratio of the accumulation area to the whole glacier surface. Their relationship must be as follows:

$$
K=\frac{k}{\mathrm{I}-k} \text {. }
$$

The data obtained in recent years have enabled some of the major characteristics of glacier regime to be determined for all areas with existing glaciers in the U.S.S.R. (see Table II). 
Table II. Some Characteristic Values of Glacier Regime

\begin{tabular}{|c|c|c|c|c|c|c|c|}
\hline Glacier areas & $\begin{array}{c}\text { Annual } \\
\text { precipitation } \\
\mathrm{mm}\end{array}$ & $\begin{array}{c}\text { Height } \\
\text { of } \\
\text { equilibrium } \\
\text { line } \\
\text { m a.s.l. }\end{array}$ & $\begin{array}{c}\text { Seasons } \\
\text { of } \\
\text { maximum } \\
\text { precipitation }\end{array}$ & $\begin{array}{l}\text { Prevailing } \\
\text { glacier } \\
\text { ratios }\end{array}$ & $\begin{array}{c}\text { Winter } \\
\text { balance } \\
\text { at } \\
\text { equilibrium } \\
\text { line } \\
\mathrm{kg} / \mathrm{m}^{2}\end{array}$ & $\begin{array}{c}\text { Vertical } \\
\text { net } \\
\text { balance } \\
\text { gradient } \\
\mathrm{mm} / \mathrm{m}\end{array}$ & $\begin{array}{c}\text { Prevailing } \\
\text { nourishment } \\
\text { type }\end{array}$ \\
\hline Arctic islands & $200-700$ & $200-700$ & winter & 0.5 & $300-700$ & 3-9 & $\begin{array}{l}\text { cold firn } \\
\text { and ice }\end{array}$ \\
\hline Polar Urals & $700-900$ & $600-1000$ & winter & $0.6-1.8$ & 2000 & ${ }^{1} 5^{-20}$ & warm firn \\
\hline Caucasus & $800-1500$ & $3000-3800$ & $\begin{array}{l}\text { autumn, } \\
\text { winter }\end{array}$ & I.0-1.5 & I $000-1400$ & 10-12 & warm firn \\
\hline Alay \& Pamir & $800-1500$ & $3800-5200$ & $\begin{array}{l}\text { winter, } \\
\text { spring }\end{array}$ & ? & $1000-1500$ & $4^{-10}$ & warm firn \\
\hline Tien Shan & $800-1300$ & $3400-4800$ & $\begin{array}{l}\text { winter, } \\
\text { sprirg }\end{array}$ & 1.0-1.5 & $300-900$ & $5^{-8}$ & warm firn \\
\hline Altay \& East Sayan & $800-1200$ & $2100-3500$ & $\begin{array}{l}\text { spring, } \\
\text { summer }\end{array}$ & $0.6-1.2$ & $500-1000$ & $3^{-6}$ & warm firn \\
\hline $\begin{array}{l}\text { Kamchatka \& Koryak } \\
\text { mountains }\end{array}$ & $600-2000$ & $600-2500$ & winter & I. $4^{-1} \cdot 7$ & I $000-2000$ & $8-15$ & warm firn \\
\hline East Siberian areas & $500-900$ & I $800-2500$ & $\begin{array}{l}\text { summer, } \\
\text { autumn }\end{array}$ & $0.8-1.6$ & $500-800$ & $4^{-5}$ & ice \\
\hline
\end{tabular}

A study of this table and some of the other data on glacier regime permits the following conclusions to be drawn. A considerable amount of precipitation is recorded almost everywhere in glacier regions including the East Siberian mountains. Annual totals of $800-1500 \mathrm{~mm}$ are predominant, and even in the East Siberian mountains they are rather high, namely above $500 \mathrm{~mm}$. The climate there cannot be as continental as was believed, but is subcontinental - so far as the niveal high-mountain zone is concerned, of course.

The main part of the snow accumulation in maritime areas falls in winter, but farther inland its period shifts to transitional seasons, and, finally, to summer. The rates of snowfall in maritime areas are 2-3 times greater than in continental ones. In all glacier areas ice melting is retarded by the summer snowfalls, but a comparatively greater influence is exerted by the latter in regions with continental climate due to their spring-summer precipitation maximum.

Ice caps with more or less complex combinations of ice domes and outlet glaciers predominate in the Atlantic-Arctic region. More widespread are the various types of mountain glaciers: valley, cirque-valley and cirque glaciers. Cirque glaciers are absolutely predominant in the Polar Urals and in the East Siberian mountains; cirque-valley glaciers are characteristic of the Caucasus, Altay and the marginal chains of Tien Shan, and valley, dendritic and transection glaciers are chiefly found in the mountains of central Asia. Besides large valley glaciers, the so-called glaciers of "Turkestan type", which are fed to a considerable extent by snow avalanches, occur in the Pamir, Alay and Tien Shan-areas characterized by a large "positive glacierization difference", i.e. where the heights of the mountains exceed appreciably the elevation of the equilibrium line on the glaciers. Among other types of glaciers should be mentioned the ice caps of high-mountain plateaus that are often found in the Tien Shan and Altay, and the star-shaped glaciers of volcanic cones, widespread in Kamchatka.

Figure I shows very generally the distribution pattern of equilibrium line elevations in different glacier areas. It should be emphasized that the elevations plotted do not present a "computed average equilibrium line" in Liestøl and Østrem's sense, but is derived from generalized data on the heights obtained for the equilibrium line by means of air-photo interpretation and field reconnaissance during the last few decades. The figures show that the equilibrium line of glaciers in the Soviet Union lies within a large altitudinal range, from 200 up to $5200 \mathrm{~m}$ above sea-level. In most parts of the country the glaciers are fed by precipitation associated with storm tracks coming from the Atlantic Ocean, and consequently the trend of the contour lines of equal equilibrium-line elevation is not an east-west zonal one. 
In fact, these lines make large angles with the parallels of latitude, and in some localities even have a north-south direction. Because of this effect the limit within each of the individual areas rises not only from the north to the south but also from the west to the east-with the exception of the glaciers of the Pacific-Asian region where, on the contrary, it rises from east to west.

At present the glacier ratio of most mountain glaciers in the country ranges from I to I.5. The relatively larger values are characteristic of areas with a maritime climate (e.g. Kamchatka and the Caucasus), and the smaller, of areas whose climate is more continental (e.g. the Altay, East Sayan and the East Siberian mountains). A glacier ratio value of 0.5 is predominant for the Atlantic-Arctic region. All these reflect the peculiarities of the glacier regimes in the present climatic period, characterized by their prevalent negative mass balance and by continuing shrinkage of the glaciers.

The intensity of the accumulation and ablation processes and values of the vertical net balance gradient depend very little upon the latitudinal position of glaciers, but display a distinct connection with the degree of continentality which appears to be characteristic for the rest of the world's glacierized areas as well (Schytt, 1967). The largest values are recorded from Kamchatka, the Polar Urals, the west Caucasus and west Pamir, areas notable for their high precipitation, whereas the smallest values are from the eastern part of the Soviet Arctic, East Siberia, the East Sayan, Altay and east Tien Shan, where the precipitation is lowest.

Nourishment by "warm" firn (or the warm infiltration type of ice formation according to Shumskiy) prevails in the majority of mountain glacier areas of the U.S.S.R. It changes to ice nourishment (i.e. nourishment by superimposed ice, infiltration-congelation type of ice formation) in the East Siberian areas with a sub-continental climate, and to ice and cold firn nourishment in the Arctic, which is also connected with the continentality of its climate.

\section{Studies of Glacier Mass Balance}

The first investigations of glacier mass balance in the U.S.S.R. were made by P. A. Shumskiy on Zemlya Frantsa-Iosifa in 1947-49. Since then they have become more numerous, especially during the International Geophysical Year, 1957-59. During I.G.Y. mass balance data were obtained for glaciers in Zemlya Frantsa-Iosifa, Novaya Zemlya, the Polar Urals, the Altay, Zailiyskiy Alatau mountains (north Tien Shan) and the Suntar Khayata range. In the following years regular observations of mass balance were continued on a number of glaciers in the Polar Urals and Zailiyskiy Alatau. The longest series of such observations (which have been going on now for ro years) are those on Lednik IGAN and Lednik Obrucheva in the Polar Urals (locality G, Fig. I) and Lednik Tsentral'nyy Tuyuksu in Zailiyskiy Alatau (E, Fig. I). The results of these are given in Table III.

Lednik IGAN and Lednik Obrucheva are in the northern part of the Polar Urals, in the basins of the Bolshaya and Malaya Khodata lakes. Lednik IGAN is an easterly flowing cirquevalley glacier, $I .8 \mathrm{~km}$ long with a maximum width of $\mathrm{I} .5 \mathrm{~km}$. It occupies an area of $\mathrm{I} .25 \mathrm{~km}^{2}$ and lies between 790 and $\mathrm{I} 240 \mathrm{~m}$ a.s.l. with its equilibrium line in recent years close to $\mathrm{I}$ ooo $\mathrm{m}$ a.s.l. Lednik Obrucheva is a cirque glacier which also flows eastwards; its length amounts to $\mathrm{I} \mathrm{km}$ and width to $0.5 \mathrm{~km}$, it covers an area of $0.4 \mathrm{~km}^{2}$, and lies within a height interval of 390 to $1075 \mathrm{~m}$ a.s.l. The elevation of the equilibrium line of this glacier is as low as $600 \mathrm{~m}$ a.s.l.

Lednik Tsentral'nyy Tuyuksu belongs to the normal valley glacier type. It lies on the northern slope of the Zailiyskiy Alatau range in the upper reaches of the Malaya Almatinka river, in the vicinity of Alma-Ata. It flows almost exactly northwards. The surrounding mountain summits rise on average to $4 \mathrm{I} 20 \mathrm{~m}$ a.s.l., and the bare-ice snout of the glacier lies somewhat above $3400 \mathrm{~m}$ a.s.l. Its length is $4 \mathrm{~km}$, the maximum width $1.2 \mathrm{~km}$, and the glacier's moraine-free portion covers an area of $2.5 \mathrm{~km}^{2}$. In recent years its equilibrium line has been located at an average height of $3740 \mathrm{~m}$ a.s.l. 
Table III. Mass Balance of Glaciers in Polar Urals and Zailiyskiy Alatau Mountains for the Last DECADE, IN $\mathrm{kg} / \mathrm{m}^{2}$

\begin{tabular}{|c|c|c|c|c|c|c|c|c|c|}
\hline \multirow[b]{2}{*}{$\begin{array}{l}\text { Budget } \\
\text { years }\end{array}$} & \multirow[b]{2}{*}{$\begin{array}{l}\text { Winter } \\
\text { balance }\end{array}$} & \multirow{2}{*}{$\begin{array}{l}\text { Lednik } \\
\text { IGAN } \\
\text { Summer } \\
\text { balance }\end{array}$} & \multicolumn{2}{|c|}{ Polar Urals } & \multirow{2}{*}{$\begin{array}{c}\text { Lednik } \\
\text { Obrucheva } \\
\text { Summer } \\
\text { balance }\end{array}$} & \multirow[b]{2}{*}{$\begin{array}{c}\text { Net } \\
\text { balance }\end{array}$} & \multicolumn{3}{|c|}{$\begin{array}{c}\text { Zailiyskiy Alatau } \\
\text { Lednik Tsentral'nyy } \\
\text { Tuyuksu* }\end{array}$} \\
\hline & & & $\begin{array}{c}\text { Net } \\
\text { balance }\end{array}$ & $\begin{array}{c}\text { Winter } \\
\text { balance }\end{array}$ & & & $\begin{array}{l}\text { Winter } \\
\text { balance }\end{array}$ & $\begin{array}{l}\text { Summer } \\
\text { balance }\end{array}$ & $\begin{array}{c}\text { Net } \\
\text { balance }\end{array}$ \\
\hline $\begin{array}{l}1957 / 5^{8} \\
1958 / 59\end{array}$ & $\begin{array}{lll}1 & 150 \\
2 & 650\end{array}$ & $\begin{array}{l}145^{\circ} \\
3000\end{array}$ & $\begin{array}{l}-300 \\
-350\end{array}$ & $\begin{array}{l}1850 \\
2900\end{array}$ & - & - & $\begin{array}{l}470 \\
200\end{array}$ & $\begin{array}{l}140 \\
620\end{array}$ & $\begin{array}{l}+330 \\
-420\end{array}$ \\
\hline $1959 / 60$ & I 400 & 2250 & -850 & I $75^{\circ}$ & 2600 & -850 & 260 & 360 & -100 \\
\hline $1960 / 61$ & 2200 & $245^{\circ}$ & $-25^{\circ}$ & 2800 & 3100 & -300 & 200 & 760 & -560 \\
\hline $1961 / 62$ & 3200 & $325^{\circ}$ & -50 & 3500 & 3700 & -200 & 180 & 870 & -690 \\
\hline I $962 / 63$ & 2100 & 3250 & -1150 & 2500 & 3500 & - I 000 & 630 & 190 & $+44^{\circ}$ \\
\hline $1963 / 64$ & I 000 & 2250 & $-125^{\circ}$ & 1100 & 2500 & -1400 & 690 & 170 & +520 \\
\hline $1964 / 65$ & 2500 & 3180 & -680 & 2420 & 2560 & -140 & - & - & -40 \\
\hline $1965 / 66$ & I $75^{\circ}$ & 1 980 & -230 & 2030 & 1720 & +310 & - & - & - I IO \\
\hline $1966 / 67$ & 2890 & 3000 & -110 & 3760 & 3470 & +290 & - & - & -30 \\
\hline
\end{tabular}

* Net balance values from Lednik Tsentral'nyy Tuyuksu for last three years are preliminary; they are estimated on the basis of observations of glacier ratios and the elevations of the equilibrium line.

Mass-balance figures for Lednik IGAN in the Polar Urals have been obtained also for an extended period preceding the I.G.Y. by calculation from meteorological data. For this purpose Khodakov (Troitskiy and others, I966) used the relationship of the maximum snow accumulation to the sum of the average monthly winter temperatures (from October to May), * and of the total ablation to the sum of mean monthly temperatures for three summer months

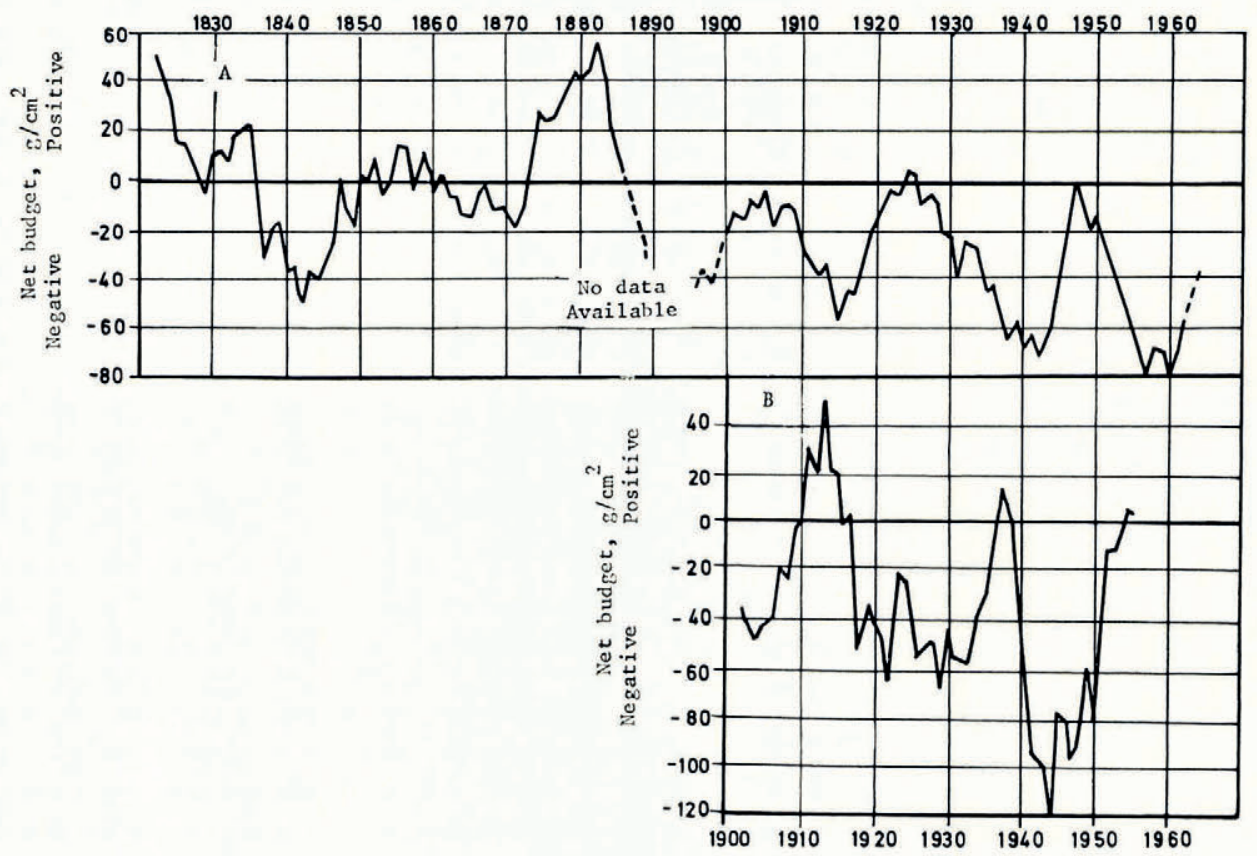

Fig. 2. Variations in mass balance of Lednik IGAN, Polar Urals, 1o-year running means (A), and of the Grosser Aletschgletscher, Swiss Alps, 5-year running means $(B) . A$-calculated and plotted on the basis of Khodakov's data (Troitskiy and others, 1966$) ; B$-after Kasser and Müller $(1960) .1 \mathrm{~g} / \mathrm{cm}^{2}=10 \mathrm{~kg} / \mathrm{m}^{2}$.

* The satisfactory correlation between accumulation and winter temperature in the Polar Urals was established as a result of direct measurement of both elements for the last i i years. 
Table IV. Average Annual Mass Balance of Lednik igan and Lednik Tsentral'nyy Tuyuksu for the Last ioo Years (Calculated on the Basis of V. Khodakov's and N. Pal'gov's data), in $\mathrm{kg} / \mathrm{m}^{2}$

\begin{tabular}{|c|c|c|c|c|c|}
\hline \multirow[b]{2}{*}{ Period of time } & \multicolumn{3}{|c|}{ Lednik $I G A \mathcal{N}$} & \multirow{2}{*}{$\begin{array}{c}\text { Lednik Tsentral'ny } \\
\text { Height of } \\
\text { equilibrium line } \\
\mathrm{m} \text { a.s.l. }\end{array}$} & \multirow{2}{*}{$\begin{array}{l}\text { Tuyuksu } \\
\text { Net } \\
\text { balance }\end{array}$} \\
\hline & $\begin{array}{l}\text { Winter } \\
\text { balance }\end{array}$ & $\begin{array}{l}\text { Summer } \\
\text { balance }\end{array}$ & $\begin{array}{c}\text { Net } \\
\text { balance }\end{array}$ & & \\
\hline $1851-1875$ & I 780 & I $74^{\circ}$ & +40 & - & - \\
\hline $1876-1900$ & 1680 & 1 660 & +20 & 3660 & +310 \\
\hline $1901-19^{2} 5$ & I 770 & I 920 & -150 & 3690 & +150 \\
\hline $1926-195^{\circ}$ & 1700 & 2030 & -330 & 3725 & -40 \\
\hline $195 \mathrm{I}-\mathrm{I} 963$ & 2200 & 2880 & -680 & 3740 & -120 \\
\hline
\end{tabular}

(June to August), which were obtained from the mass-balance observations carried out during recent years. From these the mass-balance terms and the values for the net mass balance were computed for the period since I8I 8 using the meteorological data recorded at the Syktyvkar weather station.

The curve drawn in Figure 2A represents io-year running means of net mass balance for Lednik IGAN. According to the curve, periods of positive net mass balance for the glaciers in the Polar Urals were characteristic mainly of the nineteenth century, occurring at intervals centred around 1820 (or earlier), 1835, I855 and I885. In addition, in the twentieth century, comparatively better conditions for glacier nourishment occurred at about 1905, 1925 and 1948-49. In general this agrees well with the evidence from a number of other glacierized areas in the Atlantic-Arctic glacier region, e.g. Scandinavia.

A similar computation was made, for Lednik Tsentral'nyy Tuyuksu, Zailiyskiy Alatau, by Pal'gov ( I966) on the basis of data obtained at the Alma-Ata weather station since 1879 . He worked out the height of the equilibrium line of the glacier for each of the last 85 years, and suggested an equation relating the net balance of the glacier to the height of its ebuilibrium line.

From Khodakov's and Pal'gov's results, average net balance values for 25-year intervals were calculated for both of the above-mentioned glaciers (see Table IV).

The data obtained show that the nourishment regime of mountain glaciers in the U.S.S.R. in the second half of the nineteenth century was essentially positive whereas it became negative, and grew increasingly negative, in the first half of the twentieth century.

The changes in net balance, as given in Table IV, apparently reflect the long-term trend of climatic fluctuations, in particular the maximum temperature fall in the middle of the nineteenth century and the gradual rise in temperatures that has been taking place since then. In addition, the curve in Figure 2 indicates the existence of a series of minor climatic fluctuations, with a wave-length of about 22 years, which have been superimposed on the long-term fluctuations. The reality of these cycles has been verified by the data given in Table V, in which the time intervals (approximately equal to half the length of the 22-year cycle) are selected as centred on the years of maxima and minima of the curve, and the corresponding sums of net balances are obtained by algebraical addition of the actual yearly values taken

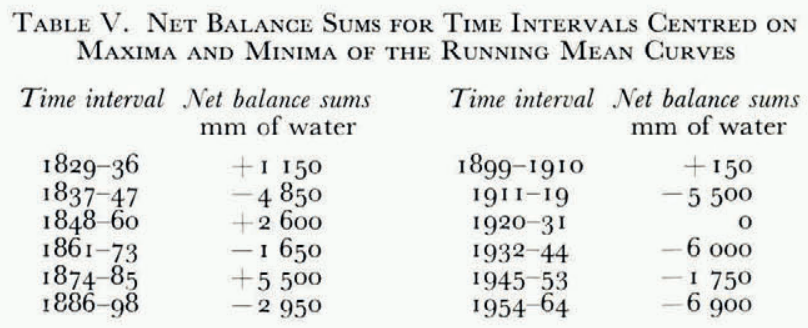


from Khodakov's table. Finally, the data listed in Table III illustrate some mass balance variations of shorter periodicity. Whilst long-term mass balance changes of mountain glaciers and the corresponding climatic fluctuations occur simultaneously all over the world, and the 22-year superimposed fluctuations occur simultaneously at least over considerable areas of continents, short-term variations prove to be metachronous.

The 22-year cycles of balance variation appear to be of especial interest. Their analogy with the 22-year cyclic fluctuations in solar activity seems to be quite evident. On the other hand, it is not less evident that these variations in the glacier mass balance cannot be a direct result of those fluctuations. That there are several intermediate variables in the chain sunglaciers is clear not only from a number of general considerations, but also from the opposing phase of the 22-year variations in mass budget of glaciers from different regions. A good illustration of this is given by comparing the mass-balance curve from Lednik IGAN (see Fig. 2A) with that from the Grosser Aletschgletscher, Swiss Alps, as published by Kasser and Müller (1960) (Fig. 2B). Both curves display balance variations which have the same wavelength but are directly opposite in their phase. Table III suggests that the same out-of-phase relationship exists between the net balance variations of the Urals and those of the Tien Shan glaciers.

Table Vi. Average Annual Mass Balance of Some Glaciers in the USSR for i957-6o in $\mathrm{kg} / \mathrm{m}^{2}$

\begin{tabular}{|c|c|c|c|c|}
\hline Name of glacier & I $957 / 5^{8}$ & I $958 / 59$ & I $959 / 60$ & References \\
\hline Lednik Shokal'skogo, Novaya Zemlya & -95 & -175 & - & \\
\hline $\begin{array}{l}\text { Guker (Hooker) island ice sheet, Zemlya } \\
\text { Frantsa-Iosifa }\end{array}$ & -370 & -420 & - & Grosval'd and others (in press) \\
\hline Lednik IGAN, Polar Urals & -300 & $-35^{\circ}$ & -850 & Troitskiy and others ( 1966 ) \\
\hline $\begin{array}{l}\text { Lednik Tsentral'nyy Tuyuksu, Zailiyskiy } \\
\text { Alatau }\end{array}$ & +330 & -420 & $-\mathrm{I} 00$ & Makarevich ( 1964$)$ \\
\hline Lednik Aktru, Altay mountains & $\begin{array}{l}\text { nearly } \\
\text { balanced }\end{array}$ & $\begin{array}{l}\text { strongly } \\
\text { negative }\end{array}$ & $\begin{array}{l}\text { slightly } \\
\text { positive }\end{array}$ & Tronov (1966) \\
\hline Glacier No. $3 \mathbf{I}$, Suntar Khayata moun- & $\begin{array}{l}+50 \\
+\end{array}$ & -320 & - & Koreysha (1963) \\
\hline
\end{tabular}

However the areas in question - the Urals on one hand, and the Tien Shan and the Alps on the other-are known to have a similar "contra-phase" relationship in terms of the succession of abnormally frequent types of atmospheric circulation (Baydal, I964). For this reason the atmospheric circulation seems to be responsible for transforming the fluctuations in solar activity into the variations in glacier nourishment.

The data obtained during the I.G.Y., make it possible to compare changes in nourishment of a number of glaciers situated in widely differing environments in several parts of the country, though for a relatively short period of time.

On the basis of the data given in Table VI the glaciers can be combined into two groups which differ from each other in the trend of their minor variations. The first group includes the glaciers of the Soviet Arctic and the Urals, whereas the glaciers of Tien Shan, Altay and East Siberia belong to the second group. These data testify to a difference in the phases of glacier regime which can be displayed not only in separate years but also over intervals of several years duration.

\section{Present Changes in Glacier Mass Balance}

Comparison of mass-balance values of Lednik IGAN, as given in Table III, with those calculated for the previous decades permits an assessment of the improvement of glacier nourishment in the 1960 's, which is characteristic of many glaciers in the Caucasus and probably in the Pamir as well. 
In the central and west Caucasus the mass balance of many glaciers was positive in this period, and the rate of their retreat slowed down abruptly, and some even advanced in 1963 (Panov, I966; Tsomaya, i965). On Mt El'brus the annual net balance of the firn area increased from year to year-from $375 \mathrm{~kg} / \mathrm{m}^{2}$ in $1956 / 57$ up to $\mathrm{I} 200 \mathrm{~kg} / \mathrm{m}^{2}$ in $\mathrm{I} 96 \mathrm{I} / 62$. (Bazhev and Bazheva, I964), and became still larger in $1962 / 63$. The annual net balance of the Lednik Fedchenko, Pamir, between ${ }^{1928}-58$ on average equalled $-0.02 \mathrm{~km}^{3}$ whereas in I958/59 it turned out positive and amounted to $0.06 \mathrm{~km}^{3}$ (Shul'ts, r962). In r959-64 the mass balance of a number of glaciers on the Pamir seemed to be positive, in any case it approached a balanced state as at that time a tendency for many previously retreating glaciers to advance was recorded.

In the Polar Urals, the accumulation exceeded the ablation in 1966 and 1967 on Lednik Obrucheva and on a number of wall-sided glaciers. The mass balance of Lednik IGAN persisted negative, but in these years was only slightly so.

However, it should be stressed that the accretion in ice mass as recorded by the balance values for several recent years did not result in a general advance of glacier fronts; on the contrary this accretion in most cases took place against the background of continuing glacier retreat.

It is most probable that at present we are witnessing the climax of the latest minor mass balance variation as suggested by Figure 2A. It is quite clear that this variation, as well as its climax, are superimposed on a very low part of the curve of long-term mass-balance variation. For this reason we consider that the present improvement in glacier nourishment cannot halt the general glacier recession.

\section{Glaciological Programmes of the I.H.D. in the U.S.S.R.}

Large-scale work is being carried on in the U.S.S.R. within the framework of the I.H.D. programmes to ascertain the present-day state of existing glaciers and the trend of their contemporary variations, and to obtain more detailed data on their regimes. This work covers: (a) The Soviet Union inventory of perennial snow and ice masses, (b) the continuous measurement of glacier variations, (c) the measurement of combined heat, mass and water balances of selected representative mountain glacier basins. Research institutes of the Akademiya Nauk (Academy of Sciences), universities and Gidrometsluzhby SSSR (the Hydrometeorological Service of the U.S.S.R.) are involved in this work. The first results of the latter were recently reported by Avsyuk and Krenke (1968).

The inventory of perennial snow and ice masses will contain, besides the usual characteristics of size, shape, and elevation of glaciers, all available data on the physical setting, structure, nourishment regime, history of the latter's variations, and data on the rivers starting at the glacier snouts, etc. The inventory must include all glaciers of an area exceeding o. $\mathrm{km}^{2}$. Each issue will be provided with a list of the literature sources.

The inventory is planned in such a way as to cover all the river basins in the upper reaches of which there are glaciers. For this purpose the whole territory of the U.S.S.R. is divided into 20 regions and each volume of the inventory will correspond to one of the regions. The regions, in turn, are divided into several basins, and a separate part of each volume will be dedicated to each of them. The whole inventory, after it has been completed, will consist of about Ioo parts comprising altogether about $4000-4500$ pages. At present, I I parts in 5 volumes (40o pages) have already been issued. They cover Zemlya Frantsa-Iosifa, the Polar and sub-polar Urals, the northern slopes of the west Caucasus, the Chilik basin of northern Tien Shan and the Kamchatka peninsula. Another 8 parts of the inventory (325 pages) are in the press. These include the Dzhungarskiy Alatau, the Fedchenko glacier basin in the Pamir, central Tien Shan and the East Sayan mountains.

The measurement of glacier variations as a part of a world-wide programme started in the U.S.S.R. in ${ }_{196} 6$ in the Polar Urals, the Altay, central Asia and the Caucasus. At present, 
a special "Manual on observations of regime variations of existing glaciers" is being completed which will contain measurement programmes of several classes differing in scale and frequency.

Investigations in representative mountain glacier basins began in the U.S.S.R. in 1966. Now observations are being carried out on 7 selected glacier basins (see Fig. I): in the west Caucasus, the upper reaches of the Marukh river with the glacier of the same name (Basin A); in the central Caucasus, upper Bakhsan river basin centred around Lednik Dzhankuat (Basin B); in the east Caucasus, Mt Kazbek area, the upper reaches of the Chkery river with Lednik Gergety (Basin C); in the Alay range, the upper reaches of the Kok-su river with Lednik Abramova (Basin D); in north Tien Shan, Zailiyskiy Alatau range-Lednik Tsentral'nyy Tuyuksu and a number of smaller glaciers in the basin of Malaya Almatinka river (Basin E); in the Altay Mountains - the basin of the Aktru river and the glacier of the same name there (Basin F), and in the Polar Urals, the upper reaches of the Bolshaya Khodata river with Lednik IGAN. These basins are being operated by the following research institutions: A-by the Institut Geografii Akademii Nauk SSSR and the Severo-Kavkazskoye Upravleniye Gidrometsluzhby SSSR, Rostov-na-Donu; B-by the Geograficheskiy Fakul'tet Moskovskogo Universiteta; C-by the Institut Geografii Akademii Nauk and the Zakavkazskoye Upravleniye Gidrometsluzhby SSSR, Tbilisi; D-by Sredneaziatskoye Upravleniye Gidrometsluzhby SSSR, Tashkent; E-by the Akademiya Nauk Kazakhskoy SSR, AlmaAta; F-by Tomskogo Universiteta, and G-by the Institut Geografii Akademii Nauk.

\section{Acknowledgements}

The authors wish to acknowledge the contribution made by their collaborators from the Otdel Glyatsiologii to the compilation of the data and in part also to its computation. Dr Herfried Hoinkes, Dr Valter Schytt, Dr Gunnar Østrem and the rest of participants of the Tarfala Glaciological Course listened to the original report and made most valuable comments. In addition Dr V. Schytt read the manuscript and Dr Michael Kelly also corrected the English. Their interest and help is gratefully acknowledged.

\section{MS. received 7 June 1968 and in revised form ${ }_{14}$ August 1968}

\section{REFERENCES}

Abbreviations used:

IANSSSRSG Izvestiya Akademii Nauk SSSR. Seriya Geograficheskaya

IVGO Izvestiya Vsesoyuznogo Geograficheskogo Obshchestva

MGIKO Materialy Glyatsiologicheskikh Issledovaniy. Khronika. Obsuzhdeniya

RMGG Rezul'taty Mezhdunarodnogo Geofizicheskogo Goda

VGK Voprosy Geografii Kazakhstana

Avsyuk, G. A., and Kotlyakov, V. M. 1967. Mountain glaciation in the U.S.S.R.: extension, classification and ice storage in glaciers. (In Oura, H., ed. Physics of snow and ice: international conference on low temperature science. ... 1966. . . Proceedings, Vol. 1, Pt. 1. [Sapporo], Institute of Low Temperature Science, Hokkaido University, p. 389-94.)

Avsyuk, G. A., and Krenke, A. N. 1968. The beginning of the Soviet glaciological investigations in the I.H.D. programme. Union de Géodésie et Géophysique Internationale. Association Internationale d'Hydrologie Scientifique. Assemblée générale de Berne, 25 sept.-7 oct. I967. [Commission de Neiges et Glaces.] Rapports et discussions, p. 292-99.

Baydal, M. Kh. 1964. Kolebaniya rezhima lednikov v svyazi s makrotsirkulyatsionnymi epokhami [Variations in glacier regime related to the macrocirculation epochs]. MGIKO, No. Io, p. I12-20.

Bazhev, A. B., and Bazheva, V. Ya. I964. Stroyeniye firnovo-ledyanoy tolshchi na yuzhnom sklone El'brusa [The structure of the firn and ice strata on the southern slope of Mt. El'brus]. MGIKO, No. ro, p. 94-Ioo.

Chizhov, O. P., and others. 1968. Oledeneniye Novoy Zemli [The glacierization of Novaya Zemlya]. [By] O. P. Chizhov [and 7 others]. RMGG. IX Razdel Programmy MGG, No. 18, 339 p.

Donchenko, E. D. I 960 . Sovremennoye oledeneniye Shapshal'skogo khrebta [The glacierization of the Shapshal range]. Informatsionnyy Sbornik o Rabotakh po $M G G$, No. 5, p. 208-17.

Govorukha, L. S. 1965 . Sovremennoye sostoyaniye oledeneniya Severnoy Zemli (itogi glyatsiologicheskikh issledovaniy $1962-63 \mathrm{gg}$.) [Present-day state of the glaciers in Severnaya Zemlya (results of glaciological investigations 1962-63)]. Doklady Akademii Nauk SSSR, Tom I63, No. 5, p. I 209-1 2. 
Govorukha, L. S. I966. O sootnoshenii prikhoda i raskhoda l'da na Ostrove Ushakova v sovremennykh klimaticheskikh usloviyakh [Mass balance of ice on Ostrov Ushakova in present climatic conditions]. IVGO, Tom 98 . Vyp. 1, p. 62-64.

Govorukha, L. S. In press. Sovremennoye oledeneniye gor Byrranga [The glacierization of the Byrranga mountains]. Problemy Arktiki i Antarktiki.

Grave, N. A., ed. 1967. Geomorfologiya vostochnoy Yakutii [Geomorphology of eastern Yakutskaya A.S.S.R.]. Yakutsk, Yakutskoye Knizhnoye Izdatel'stvo.

Grosval'd, M. G. I965. Razvitiye rel'yefa Sayano-Tuvinskogo nagor'ya [Geomorphological development of the Tuva-Sayan mountains]. Moscow, Izdatel'stvo "Nauka".

Grosval'd, M. G., and others. In press. Oledeneniye Zemli Frantsa-Iosifa [The glacierization of Zemlya FrantsaIosifa]. [By] M. G. Grosval'd [and 6 others]. RMGG. IX Razdel Programmy $M G G$.

lvan'kov, P. A. 1958. Oledeneniye Kamchatki [The glacierization of Kamchatka]. IANSSSRSG, 1958, No. 2, p. $4^{2-53}$.

Ivan'kov, P. A. 1959[a]. Oledeneniye Bol'shogo Kavkaza i yego dinamika za gody r89o-I 946 [The glacierization of the Great Caucasus and its dynamics, 1890-1946]. IVGO, Tom 91, Vyp. 3, p. 220-35.

Ivan'kov, P. A. 1959[b]. Sovremennoye oledeneniye Malogo Kavkaza i Armyanskogo nagor'ya [The glacierization of the Little Caucasus and the Armenian highlands]. Izvestiya Akademii Nauk Armyanskoy SSR. Seriya Geologii $i$ Geografii, Tom 12, No. 2, p. 47-50.

Kasser, P., and Müller, W. 1960. Über die Gletscheränderungen seit 1900 in den schweizer Alpen. Wasser-und Energiewirtschaft, i960, Nr. 8-10, p. 224-33.

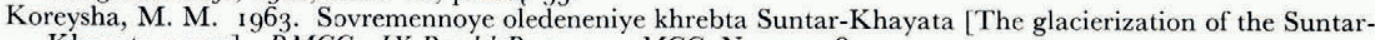
Khayata range]. RMGG. IX Razdel Programmy MGG, No. I I, $9^{8} \mathrm{p}$.

Kotlyakov, V. M. 1966 . Opyt podscheta zapasov vody, akkumulirovannoy v gornykh lednikakh Sovetskogo Soyuza [An attempt to calculate the amount of water stored in the mountain glaciers of the Soviet Union]. IANSSSRSG, 1956 , No. 3, p. $43-48$.

Makarevich, K. G. I954. Veshchestvenniy balans lednikov Zailiyskogo Alatau [Mass balance of the glaciers in Zailiyskiy Alatau]. Glyatsiologicheskiye Issledovaniya, No. 13, p. 79-84.

Malykh, M. I. 1958. Sovremennoye oledeneniye Koryakskoy gornoy sistemy [The glacierization of the Koryak mountain system]. IVGO, Tom 9o, Vyp. 6, p. 507-20.

Meier, M. F., and Post, A. S. 1962. Recent variations in mass net budgets of glaciers in western North America. Union Géodésique et Géophysique Internationale. Association Internationale d'Hydrologie Screntifique. Commission des Neiges et Glaces. Colloque d'Obergurgl, $10-9-18-91962$, p. $63-77$.

Miroshnikov, L. D. 1962 . Relikty poslednegs oledeneniya Taymyra [Remains of the last glaciation of Taymyr]. Priroda, 1962, No. 5, p. 101-02.

Pal'gov, N. N. I966. Sto desyat' let iz zhizni Tsentral'nogo Tuyuksuyskogo lednika v Zailiyskom Alatau [1 Io years of the life of Lednik Tsentral'nyy Tuyuksu in Zailiyskiy Alatau]. Vestnik Akademii Nauk Kazakhskoy SSR, I966, No. 9 (257), p. 25-36.

Panov, V. D. I966. Byudzhet massy dolinnykh lednikov basseyna reki Teberdy, Zapadnyy Kavkaz [Mass balance of the valley glaciers in the basin of the Teberda river, western Caucasus]. MGIKO, No. 12, p. 77-79.

Preobrazhenskiy, V. S. I960. Kodarskiy lednikoviy rayon, Zabaykal'ye [Kodar glacier area, Transbaykal region]. RMGG. IX Razdel Programmy MGG, No. 4, 75 p.

Preobrazhenskiy, V. S. I 963 . K voprosu o ploshchadi i chisle lednikov Tikhookeanskoy glyatsiologicheskoy provintsii v predelakh SSSR [On the question of the area and number of glaciers in the Pacific glacier region of the U.S.S.R.]. MGIKO, No. 7, p. I $^{1-52}$.

Schytt, V. ig67. A study of ablation gradient. Geografiska Annaler, Vol. 49A, Nos. 2-4, p. 327-32.

Seliverstov, Yu. P. I962. Sovremennoye i drevneye oledeneniye khrebta Saur [Present-day and former glaciations of the Saur range]. VGK, Vyp. 9, p. $175^{-88 .}$

Shul'ts, V. L., ed. I 962 . Lednik Fedchenko. Tom I-2. Tashkent, Izdatel'stvo Akademii Nauk Uzbekskoy SSR.

Shumskiy, P. A. I949. Sovremennoye oledeneniye Sovetskoy Arktiki [The glacierization of the Soviet Arctic]. Moscow, Leningrad, Izdatel'stvo Glavsevmorputi.

Shumskiy, P. A. I964. Polozheniye glyatsiologicheskikh zon na Novoy Zemle v r 954 godu [The positions of the glaciological zones in Novaya Zemlya in r954]. MGIKO, No. 9, p. 259-6o.

Svatkov, N. M., and Tsvetkov, D. G. 1965 . Issledovaniye lednikov tsentral'noy chasti Koryakskogo nagor'ya [Glaciological investigations in the central Koryak mountains]. (In Avsyuk, G. A., ed. Teplovoy $i$ vodniy rezhim snezhno-lednikovykh tolshch [Temperature and water regime of snow and ice masses]. Moscow, Izdatel'stvo "Nauka", p. 31-65.)

Troitskiy, L. S., and others. I966. Oledeneniye Urala [The glacierization of the Urals]. [By] L. S. Troitskiy [and 6 others]. RMGG. IX Razdel Programmy MGG, No. 16, 308 p.

Tronov, M. V. 1949. Ocherki oledeneniya Altaya [Sketches on the glacierization of the Altay]. Moscow, Izdatel'stvo Geograficheskoy Literatury.

Tronov, M. V. 1966. Ledniki $i$ klimat [Glaciers and climate]. Leningrad, Gidrometeorologicheskoye Izdatel'stvo.

Tronov, M. V., and Oleynik, I. Ya. 1962 . Obshchiye rezul'taty lednikovikh issledovaniy na Altaye v period Mezhdunarodnogo Geofizicheskogo Goda [General results of glaciological investigations on the Altay during the I.G.Y. period]. (In Tronov, M. V., ed. Glyatsiologiya Altaya [Glaciology of the Altay], No. I. Tomsk, Izdatel'stvo Tomskogo Universiteta, p. 3-43.)

Tsomaya, V. Sh. I 965 . Sovremenniy rost lednikov Kazbekskogo oledeneniya. [The present-day growth of Kazbek glaciers]. Trudy Zakavkazskogo Nauchno-Issledovatel'skogo Gidrometeorologicheskogo Instituta, No. 19 (25), p. $44-48$.

Vas'kovskiy, A. P. 1955. Razmery sovremennogo oledeneniya na severo-vostoke SSSR [The glacierized areas in the north-east of the U.S.S.R.]. Kolyma, No. 1o, p. $4^{2-46 .}$ 
Zabirov, R. D. 1955. Oledeneniye Pamira [The glacierization of the Pamir]. Moscow, Izdatel'stvo Geograficheskoy Literatury.

Zabirov, R. D. 1958. Oledeneniye sredney Azii [The glacierization of central Asia]. Raboty Tyan'-Shan'skoy Fiziko-Geograficheskogo Stantsii, Glyatsiologiya, Tom 1, p. 9-41.

Zenkova, V. A. 1959. Ledniki Dzhungarskogo Alatau [The glaciers of the Dzhungarskiy Alatau]. VGK, Vyp. 3, p. $138-55$.

Zenkova, V. A. 196o. Razmery oledeneniya khrebta Zailiyskiy Alatau [The glacierization of the Zailiyskiy Alatau range]. VGK, Vyp. 6, p. 139-55. 